\title{
STUDY OF SERUM ZINC LEVEL IN FULL TERM WOMEN
}

\author{
MASUDA SULTANA ${ }^{1}$, NASIM JAHAN ${ }^{2}$, NAYMA SULTANA ${ }^{3}$, MD LIAKAT ALI ${ }^{4}$
}

Assistant Professor; Department of Physiology, Dhaka Community Medical College, Dhaka, Bangladesh¹. Professor and Head, Department of Physiology, Sir Salimullah Medical College SSMC, Dhaka, Bangladesh². Assistant Professor, Department of Physiology, Sir Salimullah Medical College (SSMC), Dhaka, Bangladesh ${ }^{3}$, Associate Professor and Head, Department of Physiology, Dhaka Community Medical College, Dhaka, Bangladesh ${ }^{4}$

\begin{abstract}
Background: Micronutrient deficiency is a major problem in many developing countries. Micronutrient especially Zn deficiency may affect pregnancies, delivery, and outcome of pregnancy. Objectives: To study serum Zn level in full term mother and non pregnant women in order to compare with those of non pregnant women as reference value. Method: This cross sectional study was carried out in the Department of Physiology, Sir Salimullah Medical College Mitford Hospital, Dhaka, during the period of $1^{\text {st }}$ January 2009 to $31^{\text {st }}$ December 2009. A total number of 55 subjects were included in this study, among them 27 were full term delivery mothers (group B), treated as study group. Age range of full term mother was from 20-40 years. Again, 28 non pregnant women with age range from 20-30 years were taken as a control group. Statistical analysis was done by using appropriate method as applicable. Results: Mean serum Zn level were significantly lower $(p<0.001)$ in full term pregnant mother in comparison to those of non pregnant women. Conclusions: The present study revealed a lower level of zinc in full term mother than non pregnant women. The decreased serum Zn level may be due to poor nutritional status during pregnancy as serum total protein and albumin levels were also lower in this group of subjects.
\end{abstract}

Key Words: Zinc, full term

(Bangladesh J Physiol Pharmacol 2010; 26(1\&2) : 17-20)

\section{INTRODUCTION}

Nutritional deficiencies are common during pregnancy, especially in pregnant women from economically disadvantaged settings where diets with low minerals and vitamins are consumed. Pregnancy is associated with extraordinary metabolic demands on both the mother and developing fetus. Adequate maternal $\mathrm{Zn}$ is essential for normal embryogenesis, growth and development of human body. Zinc is important for protein synthesis, and an integral parts of several enzymes and co-factors ${ }^{1}$. Physiological changes during pregnancy include a gradual decrease of maternal serum zinc concentration. The decrease of maternal serum zinc level reflects maternal fetal transfer of zinc ${ }^{2,3}$ and the fetus is dependant on its own synthesis of transport proteins which are required for transport of zinc to all organs of its body.

Pregnant women are at higher risk of acquired $\mathrm{Zn}$ deficiency because of high uptake of $\mathrm{Zn}$ by the fetus and associated tissues. Deficiency of this may affect pregnancies, delivery and outcome of pregnancy 4 .

Address of Correspondence: Dr. Masuda Sultana, Assistant Professor of Physiology, Dhaka Community Medical College, Dhaka. Email: dr_masuda30@yahoo.com
Disturbances of micronutrient status specially zinc status in pregnant mother may occur due to severe protein calorie malnutrition, malabsorption states and prolonged diarrhea or gastrointestinal (GIT) disturbance and which contributes to the depletion of the hepatic stores of zinc. But insufficiencies may result in a reduced accumulation of these elements in storage organs of the fetus such as liver and bone 5 . Some studies have reported that maternal plasma zinc decreases during pregnancy from 24-33 week of gestation ${ }^{5,6}$.

Micronutrient deficiency is a major problem in many developing countries ${ }^{7}$. Deficiency of $\mathrm{Zn}$ may cause various reproductive health problem ${ }^{8}$ and may have some role on this regard. Some study has been done regarding this matter in abroad $^{3,9}$. But no published data is available in our country on this aspect. Again, the findings of this study may give a proper guideline and may create awareness among the obstetrician for early diagnosis of hypozincemia in pregnant women and thereby prevent the complications of pregnancy.

\section{MATERIALS AND METHODS}

The present cross sectional study was carried out in the Department of Physiology, Sir Salimullah Medical College, Mitford Hospital, Dhaka, during the period of $1^{\text {st }}$ 
January 2009 to $31^{\text {st }}$ December 2009. A total number of 55 subjects were included in this study, and all of them belonged to lower socioeconomic status. Among them 27 were full term delivery mothers (group B), treated as study group. Age range of full term mother was from 20-40 years. Again, 28 non pregnant women with age range from 20-30 years were taken as reference value (group A). Protocol of this study was approved by the ethical committee of SSMC. Subjects having history of any microbial and metabolic diseases were excluded from the study. All the pregnant mothers were selected from emergency labor word in Sir Salimullah Medical College, Mitford Hospital and non-pregnant women were selected from personal contact. After selection of the subjects, the objectives and benefits of the study were explained and written informed consent was taken from the subjects. All ethical norms were maintained. Institutional permission was taken from the Director of the Hospital. Detail personal, dietary, medical, family, socio economic, occupational histories were taken and a thorough clinical examination was done and all information was recorded in a standard prefixed questionnaire. With all aseptic precautions $5 \mathrm{ml}$ of maternal blood were drawn from medial cubital vein by disposable syringe. Blood was centrifuged at $3000 \mathrm{rpm}$ for 20 minutes. After that supernatant serum was collected in labeled eppendroff tube and from it $1 \mathrm{ml}$ of serum was transferred in a plain glass test tube for estimation of serum total protein and albumin by standard laboratory technique ${ }^{10}$ in the laboratory of Physiology Department, SSMC, Dhaka. Another $1 \mathrm{ml}$ was taken in deionized tube for estimation of serum zinc level by spectrophotometric method ${ }^{11}$ in the laboratory of Atomic Energy Commission. The statistical analysis was done by Independent-samples $t$ test and Pearson's correlation by using SPSS, Version-15.

\section{RESULTS}

Table I shows the concentration of Serum Zinc (Zn) and Hemoglobin $(\mathrm{Hb})$ in group $B$ (pregnant) and group A (control). The full term pregnant women had significantly $(p<0.001)$ lower concentration of mean serum $\mathrm{Zn}$ level than control. Again, mean blood $\mathrm{Hb}$ concentration was significantly $(p<0.001)$ lower in group B when compared to that of group A.

Table-I

Mean $\pm S D$ of Serum Zinc $(\mathrm{Zn})$ and Hemoglobin $(\mathrm{Hb})$ concentration in different groups $(n=55)$

\begin{tabular}{llcc}
\hline Groups & $\mathrm{n}$ & $\mathrm{Zn}(\mu \mathrm{g} / \mathrm{dl})$ & $\mathrm{Hb}(\mathrm{g} / \mathrm{dl})$ \\
\hline $\mathrm{A}$ & 28 & $74.32 \pm 9.13$ & $11.16 \pm 0.80$ \\
$\mathrm{~B}$ & 27 & $62.70 \pm 7.18$ & $8.89 \pm 0.65$ \\
\hline
\end{tabular}

Statistical analysis

\begin{tabular}{lll}
\hline & \multicolumn{2}{c}{$p$ value } \\
\hline A vs B & $0.001^{\star \star \star}$ & $0.001^{\star \star \star}$ \\
\hline
\end{tabular}

Group A = Apparently healthy non-pregnant women (Control group) Group B = Healthy full term delivery mother (Study group)
Table II shows the Serum Total Protein, Albumin, Globulin and Albumin/Globulin ratio in group B (pregnant) and group $A$ (control). Mean total protein, albumin and $A /$ $G$ ratio were higher in group $B$ in comparison to that of control group but it was not statistically significant. On the other hand, mean serum globulin levels were almost similar and no statistically significant difference was observed between groups A vs B.

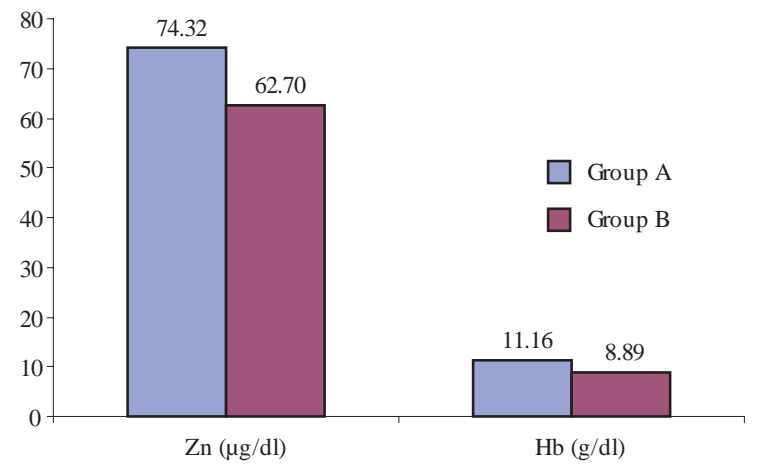

Fig.-1: Mean of Serum Zinc ( $\mathrm{Zn})$ and Hemoglobin $(\mathrm{Hb})$ concentration in different groups

Table II: Serum Total Protein, Albumin, Globulin and Albumin/Globulin ratio in different groups $(n=55)$

\begin{tabular}{lccccc}
\hline Groups & $\mathrm{n}$ & $\begin{array}{c}\text { Total Protein } \\
(\mathrm{g} / \mathrm{dl})\end{array}$ & $\begin{array}{c}\text { Albumin } \\
(\mathrm{g} / \mathrm{dl})\end{array}$ & $\begin{array}{c}\text { Globulin } \\
(\mathrm{g} / \mathrm{dl})\end{array}$ & $\begin{array}{c}\text { A/G } \\
\text { ratio }\end{array}$ \\
\hline A & 28 & $7.18 \pm 0.91$ & $4.79 \pm 0.88$ & $2.39 \pm 0.75$ & $2.23 \pm 0.87$ \\
B & 27 & $7.40 \pm 1.52$ & $4.81 \pm 1.14$ & $2.58 \pm 1.13$ & $2.26 \pm 1.16$ \\
\hline \multicolumn{5}{l}{ Statistical analysis } \\
\hline \multicolumn{5}{c}{$\mathrm{p}$ value } \\
\hline A vs B & $0.528^{\mathrm{ns}}$ & $0.938^{\mathrm{ns}}$ & $0.462^{\mathrm{ns}}$ & $0.907^{\mathrm{ns}}$ \\
\hline
\end{tabular}

Group A = Apparently healthy non-pregnant women (Control group)

Group B = Healthy full term delivery mother (Study group)

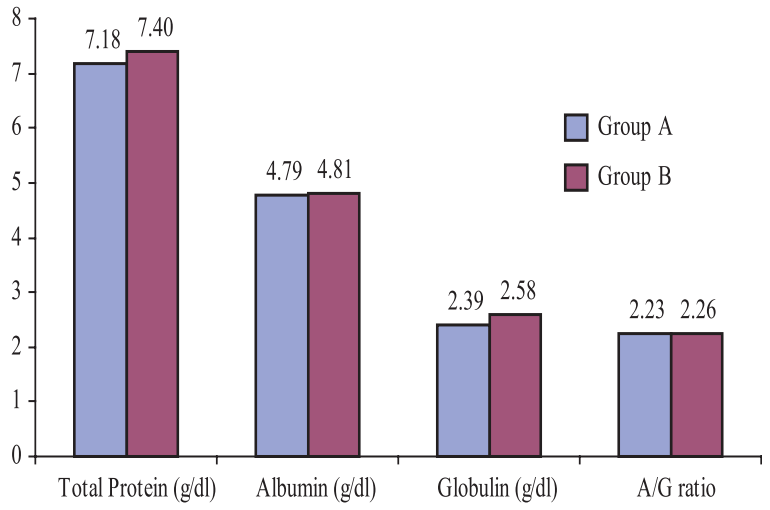

Fig.-2: Mean serum total protein, albumin, globulin and $A / G$ ratio in different groups 


\section{DISCUSSION}

The present study was undertaken to observe zinc (Zn) status in full term delivery mother and non-pregnant women by measuring their serum concentrations. In addition, their hemoglobin $(\mathrm{Hb})$ concentration was estimated to find out the malnourished mother. Moreover, serum levels of total protein, albumin, and globulin were also estimated and $A / G$ ratio was done to observe the availability of binding proteins for zinc. Again, all these parameters were also studied in the full term mother and in apparently healthy non pregnant women in order to get an idea about their normal range in our population.

In this study, all the parametric variables in healthy non pregnant women were almost similar to the reference values reported by various investigators of different countries ${ }^{3,4,12}$ and also in our country ${ }^{13,14}$.

Pregnant women in developing countries consume diets with a lower quantity of protein, minerals and vitamins ${ }^{10}$. An inadequate dietary intake before and during pregnancy is high risk factor both for mother as well as for low birth weight of the neonates ${ }^{11}$. However, there are some postulated mechanisms suggested by various investigators of different countries.

Various investigators suggested that lower level of serum $\mathrm{Zn}$ in pregnant mother might be due to its low dietary intake, increased body demand, malabsorption, increased urinary excretion and impaired utilization ${ }^{10,15}$. Grain products containing dietary fiber and phytate decrease its absorption ${ }^{16}$. Again, increased urinary excretion due to decreased availability of binding protein causes lower serum $\mathrm{Zn}$ level${ }^{17}$. It has also been suggested that low serum $\mathrm{Zn}$ concentration during pregnancy might be due to physiological hemodilution, decreased in $\mathrm{Zn}$ binding capacity, increase transfer of $\mathrm{Zn}$ from the mother to the fetus ${ }^{2,3,18}$. In addition to fetal accumulation, $\mathrm{Zn}$ is also deposited in placenta and amniotic fluid, leading to the lowering of maternal serum $\mathrm{Zn}^{15,19}$.

\section{Zn status and pregnancy outcome:}

It has been suggested that Zn deficiency may lead to defective function of estrogen, which may impair uterine contractions, cervical dilation and amniotic fluid integrity ${ }^{20}$. Furthermore, low maternal Zn status during pregnancy causes premature rupture of amniotic membrane, which in turn induces preterm labor ${ }^{21}$.

Several investigators demonstrated the relationship between low serum Zn concentration during pregnancy and small for gestational age ${ }^{22}$. It has also been suggested that low serum $\mathrm{Zn}$ concentration is closely related to adverse pregnancy outcome such as congenital malformation, fetal dysmaturity, intrauterine growth retardation and poor APGAR score ${ }^{18,23}$. In the present study, decreased serum Zn level was observed in fullterm delivery mother than non pregnant women. The decreased serum $\mathrm{Zn}$ level in fullterm delivery mother of the present study is most likely due to decreased levels of binding protein as the observed levels of them were lower and increase metabolic demand. Again poor socioeconomic status of the subjects also indicates inadequate food intake especially low dietary protein.

\section{CONCLUSION}

In this study, hypozincemia were observed in fullterm mother than non pregnant women. The decreased serum Zn level may be due to poor nutritional status during pregnancy as serum total protein and albumin levels were lower in this group of subjects.

\section{ACKNOWLEDGEMENT}

This work was supported by Department of Physiology SSMC, Dhaka and also like to thanks of Statistician Md. Noor Nabi Sayem.

\section{REFERENCES}

1. Henkin RI, Marshall JR, Meret S. Maternal fetal metabolism of copper and zinc at term. Am J Obstet Gynecol 1971; 110(1): 131-134.

2. Powell-Beard L, Lei KY, Shenker L. Effect of long term oral contraceptive therapy before pregnancy on maternal and fetal zinc and copper status. Obstet Gynecol 1987; 69: $26-32$.

3. Bro S, Berendtsen $H$, Norgaard J, Host A, Jorgensen PJ. Serum zinc and copper concentrations in maternal and umbilical cord blood. Relation to course and outcome of pregnancy. Sca J Clin Lab Invest 1988; 48: 805-811.

4. Upadhyaya C, Mishra S, Ajmera P, Sharma P. Serum iron, copper and zinc status in maternal and cord blood. Ind J Clin Bio 2004; 19(2): 48-52.

5. Perveen S, Altaf W, Vohra N, Bautista ML, Harper RG, Wapnir RA. Effect of gestational age on cord blood plasma copper, zinc, magnesium and albumin. Early Human Development 2002; 69:15-23.

6. Izquierdo Alvarez, S., Castanon, S. G., Ruata, M. L., Aragues, E. F., Terraz, P. B., Irazabal, Y. G., Gonzalez, E. G. and Rodriguez, B. G. (2007). Updating of normal levels of copper, zinc and selenium in serum of pregnant women. Journal of Trace Element Medicine and Biology 21 (Suppl.1): 49-52. ( $\underline{s})$

7. Untoro J, Muslimatun S, Karyadi E. Micronutrient supplementation and its relationship to nutritional status, health and diseases. Asia paci J clin Nutr 2002; 11: S355 - S359.

8. Hambidge $\mathrm{KM}$, Neldner $\mathrm{KH}$, Walravens PA, Zinc acrodermatitis entero pathica and congenital malformations. Lancet 1975; 8: 577-578. 
9. Atinmo $\mathrm{T}$, Mbofung $\mathrm{C}$, Osinusi BO. Relationship of zinc and copper concentrations in maternal and cord blood and birth weight. J Gynaecol Obstet 1980:452-454.

10. Mahan LK, Escott- Stump S. Nutrition during pregnancy and lactation. In: Krause's. Food, nutrition and diet therapy. $11^{\text {th }}$ edition. Philadelphia :WB Saunders company,2004: 183-189.

11. Abrams B, Newman V, Key T, Parker J. Maternal weight gain and preterm delivery. Obstet Gynecol 1989; 74: 577-583.

12. Simmer K, Thompson RPH. Maternal zinc and intrauterine growth retardation. Clin Sci 1985; 68: 395-399.

13. Azad AK. Maternal plasma zinc concentration with fetal growth (M.Phil thesis).Department of Biochemistry. Institute of Postgraduate Medicine and Research Dhaka, 1990.

14. Rahman H. Maternal zinc status and fetal outcome (M. Phil thesis). Department of Biochemistry. Dhaka Medical College. University of Dhaka. Bangladesh, 2004.

15. Jeswani RM, Vani SN. A study of serum zinc levels in cord blood of neonates and their mothers. Ind J Ped 1991; 58: 683-687.

16. Ward RJ, Abraham R, Mcfadyen IR, Haines AD, North WRS, Patel M, Bhatt RV. Assessment of trace metal intake and status in a Gujerati pregnant Asian population and their influence on the outcome of pregnancy. $\mathrm{Br} \mathrm{J}$ Obstet Gynecol 1988; 95: 676- 682.

17. Curthbertson PD, Fell SG, Smith MC, Tilstone JW. Effects of severity, nutrition and environmental temperature on protein, pottassium, zinc and creatine. Br J Surg Soc 1972; 59:925-931.

18. Tamura T, Goldenberg RL, Johnston KE, Dubard M. Maternal plasma zinc concentrations and pregnancy outcome. Am Soci Clin Nutr 2000; 71: 109-113.

19. Swanson CA, King JC. Reduced serum zinc concentration during pregnancy. Obstet Gynecol 1983; 62(3): 313-8.

20. Cunnane SC. Foetal mortality in moderately zinc deficient rats is strictly 1related to the process of parturation : effect of maternal essential fatty acid supplementation. Br J Nutr 1982; 47:495-504.

21. Scholl TO, Heliger ML, Scholl JI, Fischer RL, Khoo C. Low zinc intake during pregnancy: Its association with preterm and very preterm delivery. Am J Epi 1993; 137(10): 11151124.

22. Iqbal ASM, Shahidullah, Islam N, Akhter S, Banu S. Serum zinc and copper levels in the maternal blood and cord blood of neonates. Ind J Ped 2001; 68(6) : 523-526.

23. Black RE. Micronutrients in pregnancy. Br J Nutr 2001; 85(2): S193-S197. 